\title{
BILE LOSS DAMAGES THE CEREBELLAR PURKINJE CELLS IN RATS
}

'EmelyanchikS.V. (semel@grsu.by),2ZimatkinS.M. (smzimatkin@mail.ru)

'Educational Institution "Ya. Kupala Grodno State University", Grodno, Belarus

2Educational Institution "Grodno State Medical University", Grodno, Belarus

\begin{abstract}
Aim: The aim of the study was the estimation of the structural and metabolic changes in cerebellar Purkinje cells of rats during the complete outside bile abduction.

Material and methods: Experiments were performed on male Wistar rats weighing 200-250 g. In 26 rats the fistula of the common bile duct was made and all the bile secreted by the liver was collected through a plastic tube into the outside glass bile container. 20 animals of the control group underwent sham operation (no removal of bile). On the 1th, 3th, and 5th days after the operation the animals of the control and experimental groups were decapitated and cerebellum cortex samples were collected for histology and cytochemistry.

Results: The loss of bile induced the gradual increase in structural and metabolic abnormalities of Purkinje cells resulting in severe, irreversible disturbances and even death of some of them. The gradual decrease in Purkinje cells size, the loss of their sphericity and elongation, followed by inhibition of succinate-, NADH-, glucose-6-phosphatedehydrogenases and the activation of lactate dehydrogenase and the marker enzyme of lysosomes acid phosphatase were revealed. All the changes reflect the ratio of the processes of damage and adaptation in the affected neurons in bile absence in the body.

Conclusion: Total loss of bile (on the 1st, 3rd, and 5th days) induces the gradual increase in structural and metabolic disturbances in cerebellum Purkinje cells and death of some of them.
\end{abstract}

Keywords: cerebellum, Purkinje cells, structure, cytochemistry, loss of bile.

\section{Introduction}

Bile is an important biological fluid, secreted by the liver and flows through the common bile duct into the duodenum. Bile contains bile acids (BAs), phospholipids, cholesterol, bilirubin, proteins, water and salts. The primary BAs are synthetized from cholesterol in the liver, conjugated to glycine or taurine to increase their solubility, secreted into bile, concentrated in the gallbladder during fasting, and expelled in the intestine in response to dietary fat, as well as bio-transformed in the colon to the secondary BAs by the gut microbiota, reabsorbed in the ileum and colon back to the liver. BAs in the intestine not only regulate the digestion and absorption of cholesterol, triglycerides, and fat-soluble vitamins, but also play a key role as signaling molecules in modulating epithelial cell proliferation, gene expression, and lipid and glucose metabolism by activating farnesoid $\mathrm{X}$ and $\mathrm{G}$-protein-coupled bile acid receptor-1 in the liver, intestine, muscle and brown adipose tissue [1]. BAs receptors expressed in endothelial cells and may have important effects on both systemic and portal circulation [2]. The roles of BA in the pathogenesis of diabetes, obesity, metabolic syndrome, and cardiovascular diseases are seriously being considered, and BA and their derivatives seem to represent novel potential therapeutics to treat these diseases of civilization [3].

Obstructive (mechanical) jaundice induced by bile stones or malignancies preventing the normal outflow of bile and induces inexorably progressing hyperbilirubinemia with its consequent deleterious effects [4]. It requires a surgical treatment followed by external biliary drainage. The early and adequate decompression of bile ducts decreases postoperative complications, but lead to the external loss of bile [5]. The long-term loss of bile induces the disturbances in the digestion of lipids, in blood coagulation and other symptoms of vitamin $\mathrm{A}, \mathrm{B}, \mathrm{D}, \mathrm{E}$, and
$\mathrm{K}$ deficiencies, in calcium metabolism disorder followed by bone osteomalation, disturbances in acid-base balance of blood and functions of the liver, kidneys and nervous system [6]. In our previous studies we found that 3-5 days of external biliary drainage (with full loss of bile) in rats induces the severe structural and metabolic disturbances in brain histaminergic neurons [7] as well as in neurons of parietal brain cortex [8]. The aim of the present paper was the estimation of histological changes in the cerebellum, in particular in its Purkinje cells, in rats in the similar setting of bile loss.

\section{Material and methods}

Animals, experimental design and chemicals

Experiments were performed on 40 male Wistar rats weighing $200 \pm 25$ g. Rats were housed in vivarium with free access to standard laboratory food and kept under controlled environmental conditions. All experimental procedures complied with European Community Council Directive (86/609/EEC) for care and use of laboratory animals. This study was approved by the Biomedical Ethics Committee of the Grodno State Medical University.

In 20 rats the proximal part of common bile duct (3-5 $\mathrm{mm}$ below the confluence of the lobular hepatic ducts) was cut, ligated and all the bile secreted by the liver was collected through a polyethylene catheter into the outside glass bile container. The container was fixed to the skin on the right side of the rat body. 20 animals of the control group underwent sham operation (no removal of bile). On the 1th, 3th, and 5th days after the operation the animals of the control and experimental groups were anesthetized with ethylic ether and decapitated. The samples of their cerebellum were collected and fixed in the mixture of alcohol, chloroform and acetic acid in the ratio of $6: 3: 1$, then treated with alcohol and xylen and embedded in paraffin. Other pieces of cerebellar cortex were frozen and stored in liquid nitrogen 
for further cytochemistry. All the chemicals were obtained from Sigma-Aldrich (USA).

\section{Histology}

$7 \mu \mathrm{m}$ paraffin sagittal sections of the cerebellum cortex were stained with hematoxylin and eosin, $0.1 \%$ solution of thionine (the Nissl method) to assess general cytology of neurons and for the identification of dying neurons [9]. The examination of histological preparations, their microphotography and morphometry was carried out using microscope Axioskop 2 plus) equipped with digital camera Axiocam MRc5 (Carl Zeiss, Germany). In the preparations stained by the Nissl method the total amount of cerebellum Purkinje cells in the $1 \mu \mathrm{m}$ interval of cortex gyrus was estimated, as well as the amount of normal and pathological types of neurons according to the intensity of their cytoplasm chromatophilia and the shape of cells bodies: normochromic (normal, medium staining), hyperchromic (intense staining), hyperchromic shrunken, hypochromic (pale staining) and shadow cells (very pale remnants of dead neurons).

Morphometry and cytophotometry of Purkinje cells in paraffin sagittal sections stained by the Nissl method were carried out using computer image analysis software Image Warp (Bit Flow, USA). To estimate the size and shape of neuronal bodies the images of up to 30 neurons bodies on the computer monitor were outlined by mouse cursor. Maximal and minimal diameter (D), perimeter $(\mathrm{P})$, square (S), as well as form-factor $(4 \pi \mathrm{S} / \mathrm{P} 2$ - parameter of sphericity and folding) and the factor of elongation (maximal D/minimal D - parameter of sphericity) were calculated.

\section{Cytochemistry}

$10 \mu \mathrm{m}$ frozen sagittal sections of the cerebellum were prepared using cryostat (Leica CM 1840, Germany). The activity of the oxidizing enzymes, such as succinate dehydrogenase (SDH, EC 1.3.99.1), lactate dehydrogenase (LDH, EC 1.1.1.27), glucose-6-phosphate dehydrogenase (G-6-PDH, EC 1.1.1.49), NADH dehydrogenase (NADHDH, EC,
1.1.1.49), as well as the activity of marker enzyme of lysosomes acid phosphatase (AP, EC 1.4.3.4) were examined [10]. For the enzyme histochemistry the cryostat sections were placed into the corresponding incubation medium, including the buffer, substrate, co-factor, if necessary, and chromogen, for $30 \mathrm{~min}$ - 5 hours to visualize the location of enzymatic activity, then washed and embedded in the suitable plastic medium. The content of RNA in Purkinje cells cytoplasm was examined in paraffin sections by the Einarsson method [10]. The enzyme activities or products of histochemical reactions were determined in the cytoplasm of neurons on the optic density of chromogen obtained in the course of histochemical reactions. In each experimental group 150-200 neurons were estimated.

\section{Statistics}

The mean values obtained for every animal were processed with nonparametric statistics (because of the small number of animals in the groups) using software STATISTICA 10 (StatSoft, Inc., USA). In descriptive statistics, the values of median (Me) and interquartile range (IQR) were determined. The differences were considered significant at $\mathrm{p}<0.05$ (Mann-Whitney U-test) because it was not a normal distribution.

\section{Results \\ Histology}

At the light microscopic level following 1 day of bile loss no structural changes in cerebellum Purkinje cells were found. Following 3 days of bile loss the shape of Purkinje cells became various: elongated, oval or triangle, but not pear-shaped only. The hyperchromic shrinking and dead neurons appeared. Following 5 days of bile loss the destructive changes in Purkinje cells increased. Highly elongated cells with extended apical dendrites and lyses of chromatophylic substance, or swelling of nucleus and cytoplasm, deformation and division of nuclei appeared (Fig. 1, 2). The single shadow cells were also observed. But there remained the cerebellum cortex regions where neurons were still unchanged.
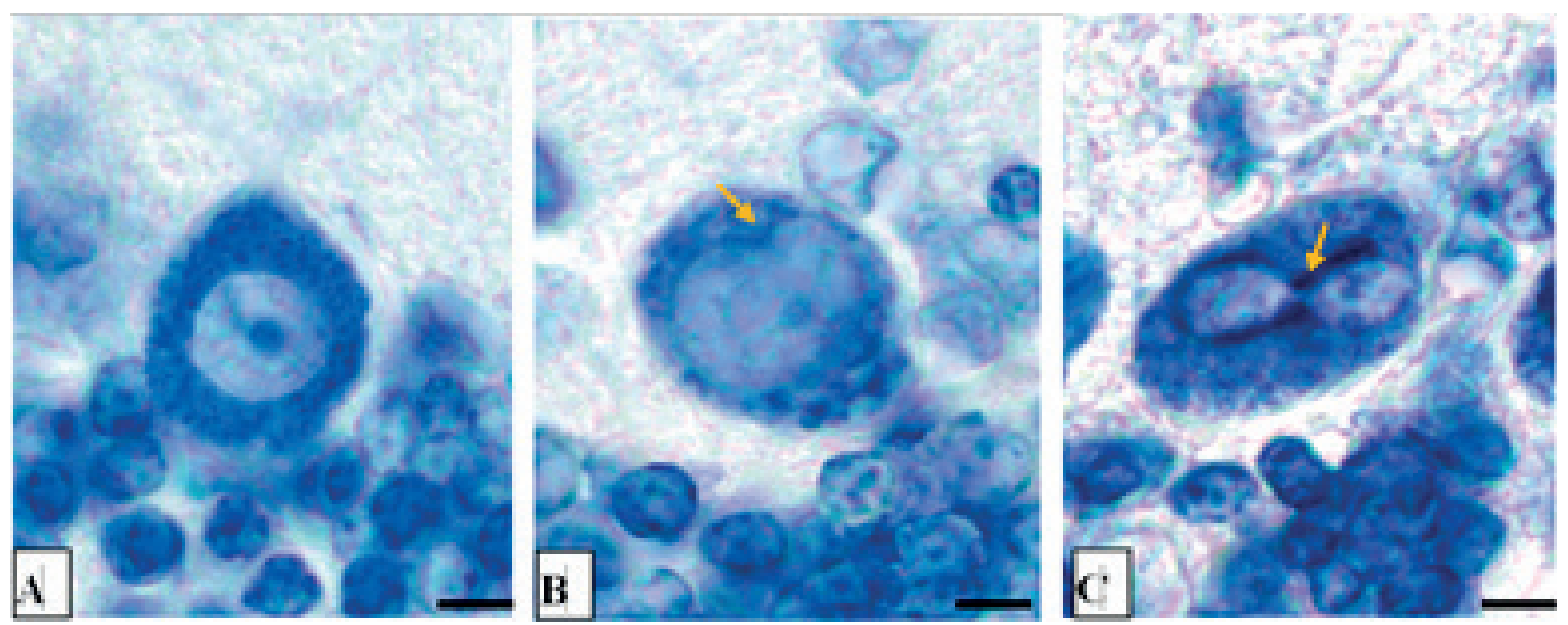

Figure 1. - The cerebellum Purkinje cells. A - control (5 days after the sham operation); B, $C$ - 5 days of bile loss ( $B$-swelling of nucleus, $C$-division of nucleus). Nissl staining. Digital microphotography. Magnification $\times 1000$. Scale bars $-5 \mu \mathrm{m}$ 

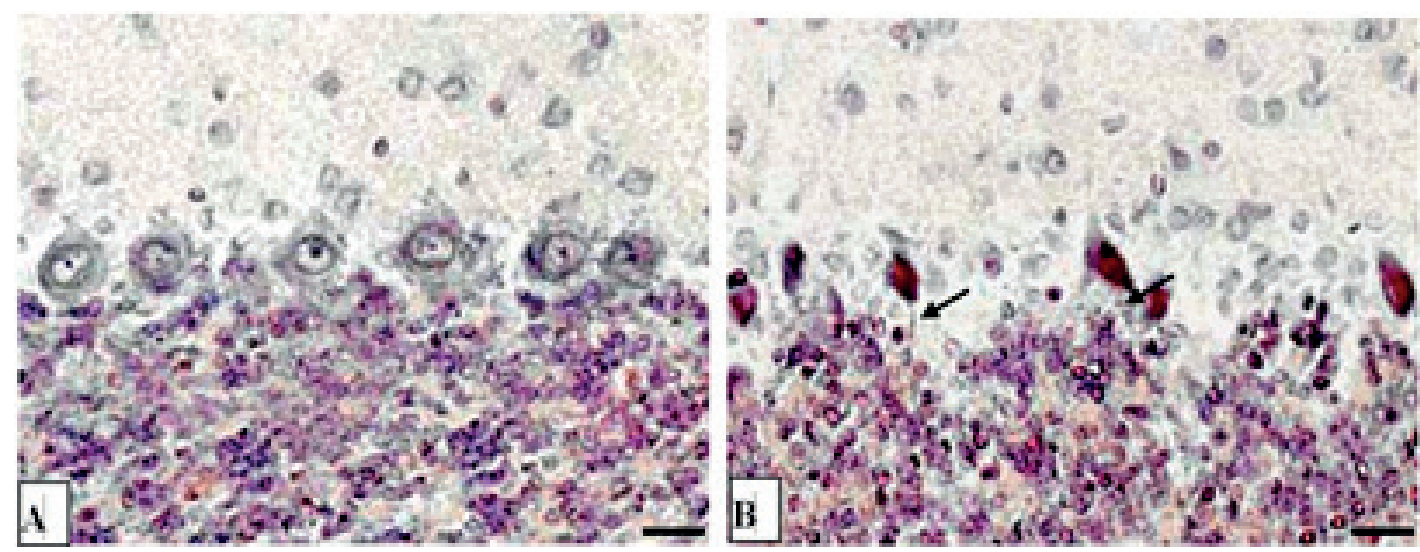

Figure 2. - The cerebellum Purkinje cells. A - control (5 days after the sham operation); $B$ - 5 days of bile loss (hyperchromic shrunken Purkinje cells, purple staining). Victorov et al. staining. Digital microphotography.

Magnification $\times 200$. Scale bars $-10 \mu \mathrm{m}$

The calculation of Purkinje cells have revealed that the amount of hyperchromic neurons on the 5th day of bile loss increased 3,8-fold ( $\mathrm{p}=0,009$ ), hyperchromic shrunken neurons increased 34,4-fold $(\mathrm{p}=0,009)$, a shadow cells $-7,5$-fold $(\mathrm{p}=0,037)$. The amount of dead neurons estimated by the Victorov method increased 28 -fold $(\mathrm{p}=0.018)$. In dynamics of bile loss the gradual decrease in Purkinje cells size, their elongation and loss of sphericity took place (Fig. 3).
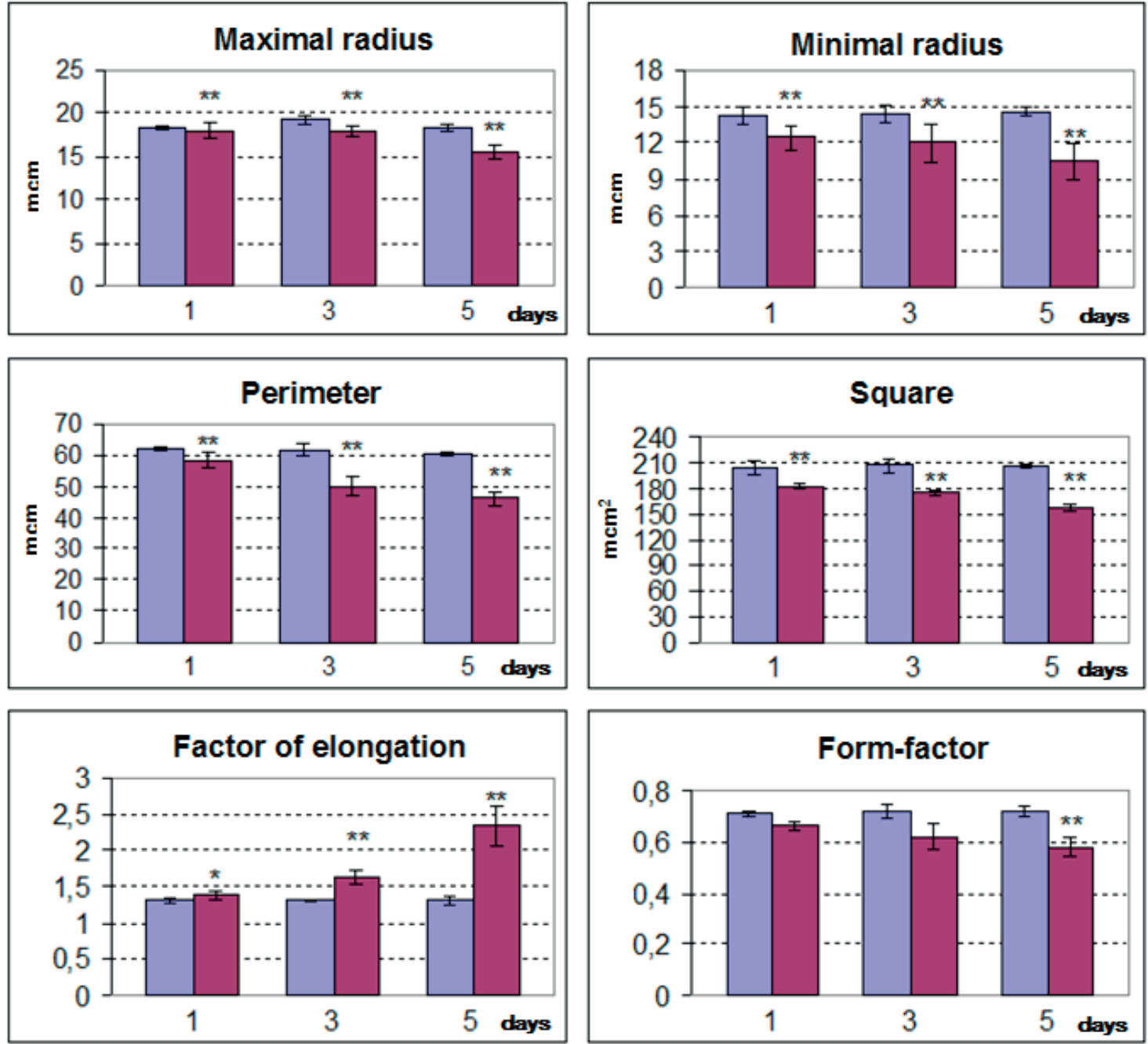

Figure 3. - Changes in size and shape of cerebellum Purkinje cells in dynamics of bile loss. Me $\pm I Q R ; *_{-p}<0,05,{ }^{*} *_{-p}<0,01$ as compared to controls 


\section{Histochemistry}

The loss of bile induces the gradual decrease in Purkinje cells cytoplasm, the activity of the mitochondria marker enzyme succinate- and NADH-

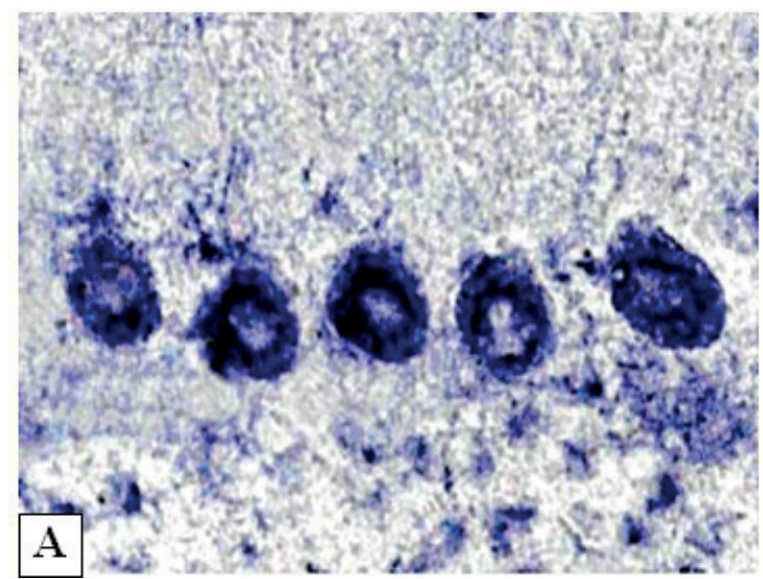

dehydrogenase, as well as glucose-6-phosphate- and $\mathrm{NADH}$ dehydrogenase (NADHDH, EC, 1.1.1.49) and the activation of lactate dehydrogenase and the marker enzyme of lysosomes acid phosphatase (Fig. 4-7).

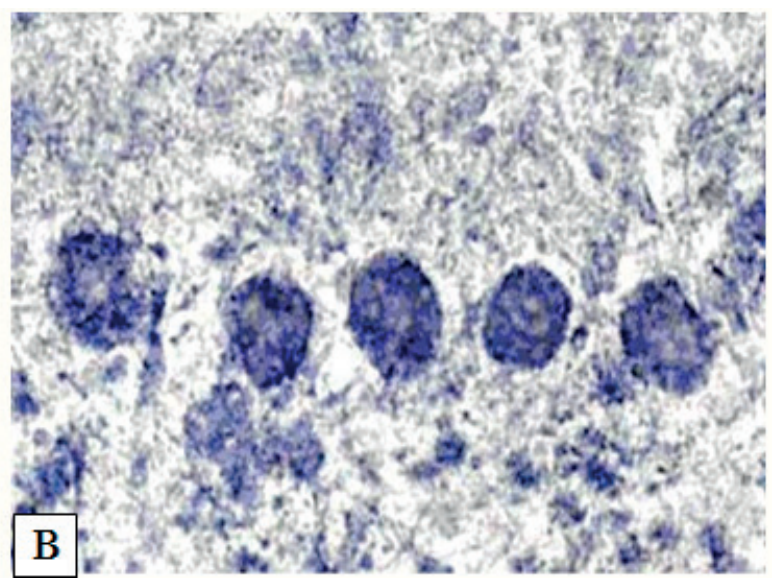

Figure 4. - Activity of succinate dehydrogenase in cerebellum Purkinje cells.

A-controls (5 days after sham operation); $B-5$ days of bile loss (lower staining in cytoplasm). According to Nachlas et al. Digital microphotography. Magnification $\times 400$. Scale bars $-10 \mu m$
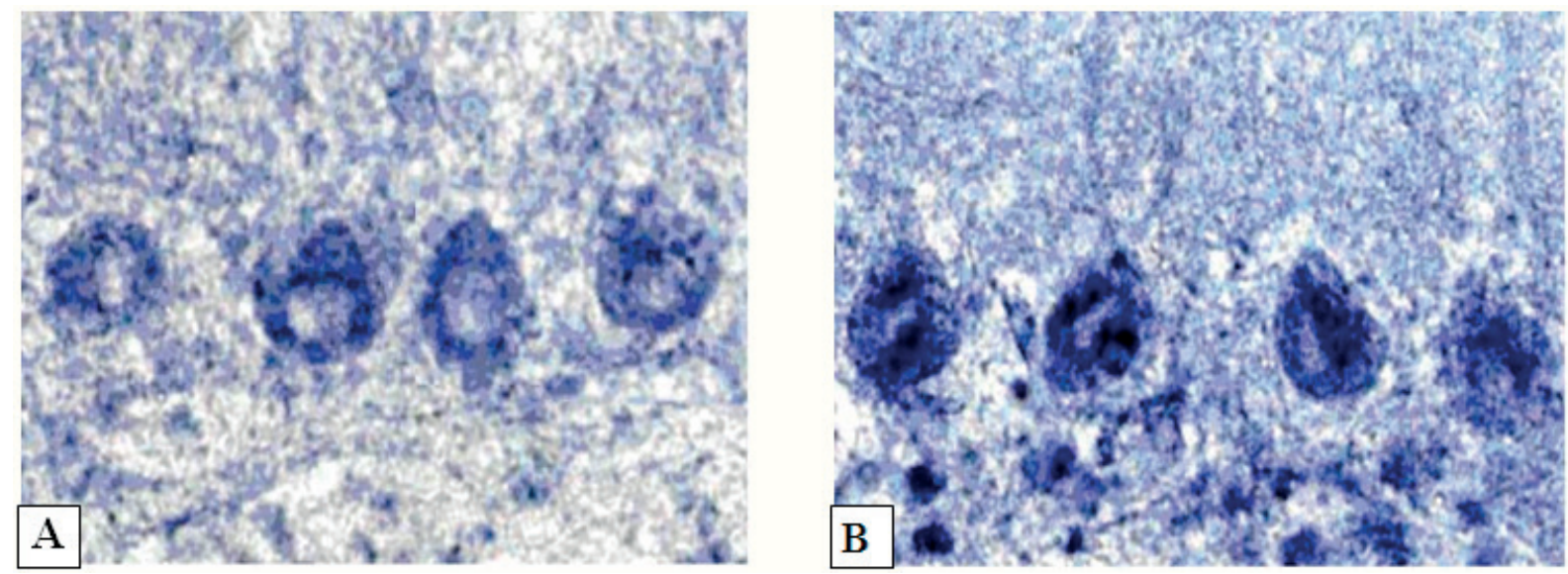

Figure 5. - Activity of lactate dehydrogenase in cerebellum Purkinje cells.

$A$ - controls (5 days after sham operation); $B$ - 5 days of bile loss (higher staining in cytoplasm). According to Hess, Scarpelli and Pearse. Digital microphotography. Magnification $\times 400$. Scale bars $-10 \mu \mathrm{m}$
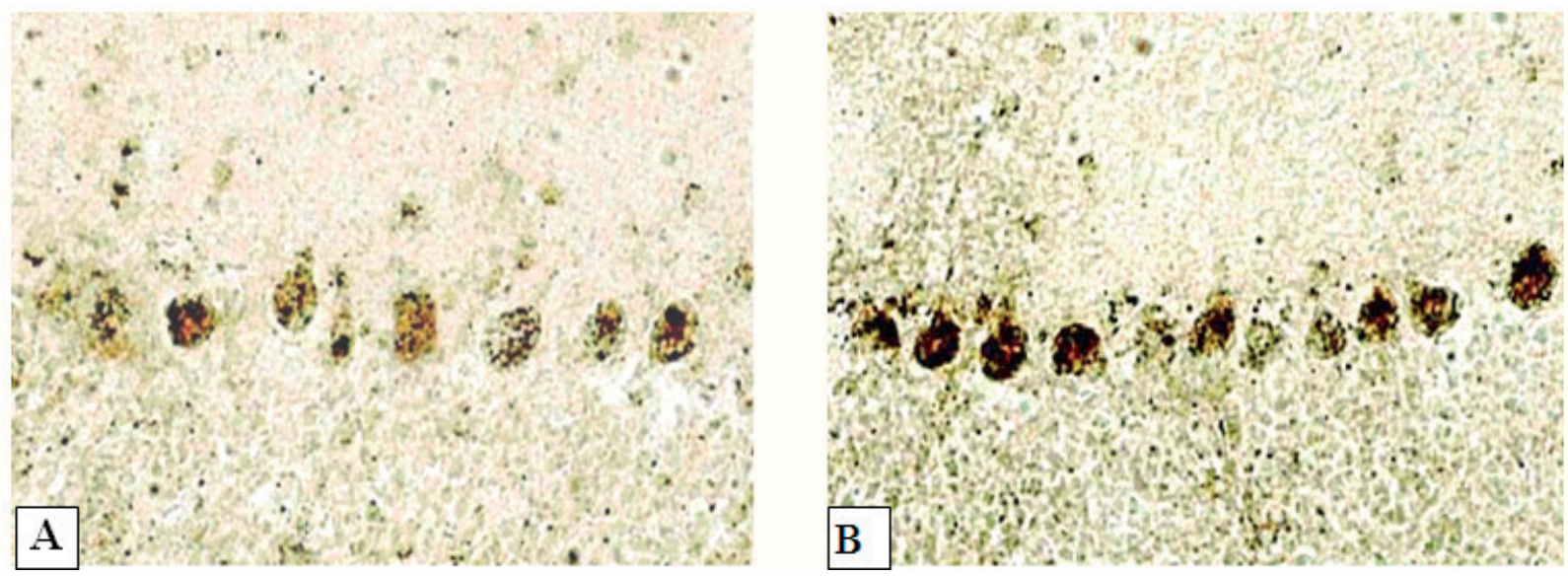

Figure 6. - Activity of acid phosphatase in cerebellum Purkinje cells.

A-controls (5 days after sham operation); B - 5 days of bile loss (higher staining in cytoplasm). According to Gomori. Digital microphotography. Magnification $\times 200$. Scale bars $-10 \mu \mathrm{m}$ 

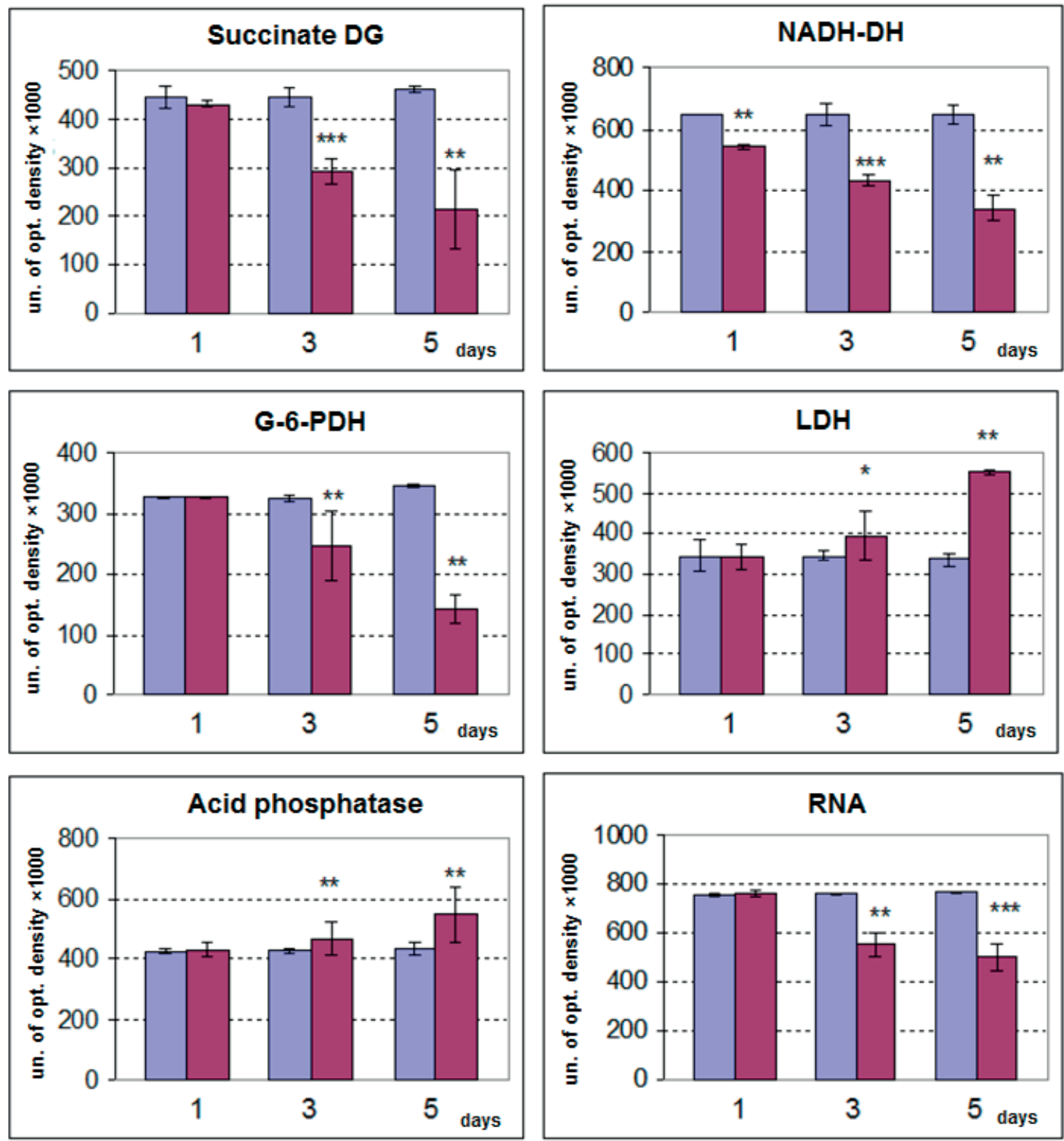

Figure 7. - Changes of enzyme activities and RNA contents of cerebellum Purkinje cells cytoplasm in dynamics of bile loss. $\mathrm{Me} \pm I Q R ;{ }^{*}-p<0,05, * *-p<0.01$ as compared to controls

\section{Discussion}

In our previous paper following bile loss in rats we found similar dramatic structural and metabolic disturbances in brain histaminergic and parietal cortex neurons $[7,8]$. The removal of bile from the body in the present study induces the increase in the number of hyperchromic shrunken Purkinje cells and shadow cells, which seems to be too severe for neurons to survive [11]. The decrease in size, loss of sphericity and elongation of neurons took place probably as a result of rise of osmolarity of intercellular fluid. The shrinkage of neurons occurs through the activation of $\mathrm{Na}^{+}-\mathrm{K}^{+}-2 \mathrm{Cl}^{-}$transport systems or coupled $\mathrm{Na}^{+} / \mathrm{H}^{+}$и $\mathrm{Cl}^{-} / \mathrm{HCO}_{3}^{-}$pathways of metabolism [11, 12]. The shape of neurons can be disturbed also by the damage of cytoskeleton.
One of the possible reasons of cell membranes damage and structural disturbances of neurons can be the loss of cholesterol, which is included into the composition of biological membranes and supplied by other organs to the liver for the synthesis of biologically important substances - bile acids, which are lost during the removal of bile. In addition, in the loss of bile and absence of its entering the duodenum, a long-term afferent impulsion from duodenum results in the process of central inhibition.

\section{Conclusion}

The loss of bile induces the gradual increase in structural and metabolic abnormalities in Purkinje cells resulting in severe, irreversible disturbances (hyperchromic shrunken neurons) and the death 
of some of them. A gradual decrease in Purkinje cells size, the loss of sphericity and elongation of neurons, followed by the activation of succinate-, NADH-, glucose-6-phosphate-dehydrogenases and activation of lactate dehydrogenase and acid phosphatase take place. All these changes reflect the ratio of the processes of damage and adaptation in the neurons in the settings of bile absence in the body.

\section{Литература}

1. Bile Acid Physiology / A. Di Ciaula [et al.] // Annals of Hepatology. - 2017. - Vol. 16, suppl. 1. - P. 4-14. - doi: 10.5604/01.3001.0010.5493.

2. Arab, J. P. Bile Acids and Portal Hypertension / J. P. Arab, F. Barrera, M. Arrese // Annals of Hepatology. - 2017. - Vol. 16, suppl. 1. - P. 77-80. - doi: 10.5604/01.3001.0010.5500.

3. Vitek, L. Bile Acids in the Treatment of Cardio metabolic Diseases / L. Vitek // Annals of Hepatology. - 2017. - Vol. 16, suppl. 1. - P. 43-52. - doi: 10.5604/01.3001.0010.5496.

4. Current Status of Percutaneous Transhepatic Biliary Drainage in Palliation of Malignant Obstructive Jaundice: A Review / S. H. Chandrashekhara [et al.] // Indian Journal of Palliative Care. - 2016. - Vol. 22, № 4. - P. 378-387. doi: 10.4103/0973-1075.191746.

5. Mirzoian, S. Early compensation for the loss of bile during external drainage / S. Mirzoian, M. Bahdasarian, S. Shahbazian // Georgian medical news. - 2007. - Vol. 151. - P. 7-10.

6. Enderlin, F. E. Long term bile collection in the rat / F. E. Enderlin, T. Honohan // Laboratory Animal Science. 1977. - Vol. 27, № 4. - P. 490-493.

7. Zimatkin, S. M. Structural-metabolic changes in histaminergic neurons of the rat hypothalamus in conditions of loss of bile / S. M. Zimatkin, O. V. Baraban, S. V. Emelyanchik // Neuroscience and Behavioral Physiology. - 2008. - Vol. 38, № 9. - P. 907-911. - doi: 10.1007/ s11055-008-9069-3.

8. Emelyanchik, S. V. Structural and Histochemical Changes in Rat Parietal Cortex Neurons during Biliary Drainage / S. V. Emelyanchik, S. M. Zimatkin // Neuroscience and Behavioral Physiology. - 2013. - Vol. 43, № 3. - P. 329335.

9. Victorov, I. V. Improved selective, simple, and contrast staining of acidophilic neurons with vanadium acid fuchsin / I. V. Victorov, K. Prass, U. Dirnagl // Brain Research. Brain Research Protocols. - 2000. - Vol. 5, № 2. - P. 135-139.

10. Everson Pearse, A. G. Histochemistry - theoretical and applied / A. G. Everson Pearse. - 2nd ed. - Boston : Little, Brown \& Co, 1960. - 998 p.

11. Lang, F. The diversity of volume regulatory mechanisms / F. Lang, G. I. Buch, H. Volke // Cellular Physiology \& Biochemistry. - 1998. - Vol. 8 (1-2). - P. 1-45.

12. Strange, K. Cellular and molecular physiology of volume - sensitive anion channel / K. Strange, F. Emma, P.
Acknowledgements - The authors are grateful to Olga A. Karnyushko for the technical assistance and the English translator Yanina Razvodovskaya for the correction of the manuscript.

Funding - Grodno State Medical University grant for reagents and animals.

Conflict of interest statement. None declared.

S. Jachson // American Journal of Physiology. - 1996. - Vol. 270 (3, pt. 1). - P. 711-730. - doi: 10.1152/ajpcell.1996.270.3.C711.

\section{References}

1. Di Ciaula A, Garruti AG, Baccetto RL, Molina-Molina E, Bonfrate L, Wang DQ, Portincasa P. Bile Acid Physiology. Annals of Hepatology. 2017;16(1):4-14. doi: 10.5604/01.3001.0010.5493.

2. Arab JP, Barrera F, Arrese M. Bile Acids and Portal Hypertension. Annals of Hepatology. 2017;16(1):77-80. doi: 10.5604/01.3001.0010.5500.

3. Vitek L. Bile Acids in the Treatment of Cardio metabolic Diseases. Annals of Hepatology. 2017;16(1):43-52. doi: 10.5604/01.3001.0010.5496.

4. Chandrashekhara SH, Ganamagatti S, Singh A, Bhatnagar S. Current Status of Percutaneous Transhepatic Biliary Drainage in Palliation of Malignant Obstructive Jaundice: A Review. Indian Journal of Palliative Care. 2016;22(4):378-387. doi: 10.4103/0973-1075.191746.

5. Mirzoian S, Bahdasarian M, Shahbazian S. Early compensation for the loss of bile during external drainage. Georgian medical news. 2007;151:7-10.

6. Enderlin FE, Honohan T. Long term bile collection in the rat. Laboratory Animal Science. 1977;27(4):490-493.

7. Zimatkin SM, Baraban OV, Emelyanchik SV. Structuralmetabolic changes in histaminergic neurons of the rat hypothalamus in conditions of loss of bile. Neuroscience and Behavioral Physiology. 2008;38(9):907-911. doi: 10.1007/s11055-008-9069-3.

8. Emelyanchik SV, Zimatkin SM. Structural and Histochemical Changes in Rat Parietal Cortex Neurons during Biliary Drainage. Neuroscience and Behavioral Physiology. 2013;43(3):329-335. doi:10.1007/s11055013-9735-y

9. Victorov IV, Prass K, Dirnagl U. Improved selective, simple, and contrast staining of acidophilic neurons with vanadium acid fuchsin. Brain Research. Brain Research Protocols. 2000;5(2):135-139.

10. Everson Pearse AG. Histochemistry theoretical and applied. 2nd ed. Boston: Little, Brown \& Co; 1960. 998 p.

11. Lang F, Buch GI, Volke H. The diversity of volume regulatory mechanisms. Cellular Physiology \& Biochemistry. 1998;8(1-2):1-4.

12. Strange K, Emma F, Jachson PS. Cellular and molecular physiology of volume - sensitive anion channel. American Journal of Physiology. 1996;270(3 Pt 1):711-730. doi: 10.1152/ajpcell.1996.270.3.C711. 


\title{
КЛЕТКИ ПУРКИНЬЕ КОРЫ МОЗЖЕЧКА ПРИ ОТВЕДЕНИИ ЖЕЛЧИ У КРЫС
}

\author{
'Емельянчик С. В., ${ }^{2}$ Зиматкин С. М.
}

'УО «Гродненский государственный университет имени Янки Купалы», Гродно, Беларусь 2УО «Гродненский государственный медицинский университет», Гродно, Беларусь

Цель исследования - оценка структурных и метаболических изменений в клетках Пуркинье коры мозжечка крыс при полном наружном отведении желчи.

Материал и методы. Эксперименты выполнены на крысах-самиах Wistar, массой 200-250 г. У 26 крыс в области ворот печени в общий желчный проток вводили и фиксировали катетер из пластика, всю желчь, секретируемую печенью, собирали в стеклянную емкость, закрепленную снаружи. 20 животным контрольной группы провели ложную операцию (желчь не отводили). Через одни, трое и пять суток после операции животных контрольной и опытной групп выводили из эксперимента, а образиь коры мозжечка забирали для гистологического и гистохимического исследования.

Результаты. Потеря желчи вызывала постепенное увеличение структурных и метаболических нарушений в клетках Пуркинье, что приводило к тяжельм, необратимым нарушениям и даже гибели некоторых из них.Установлено постепенное уменьшение размеров перикарионов клеток Пуркинье, потеря их сферичности и увеличение больиого радиуса, а также ингибирование сукиинат-, NADH-, глюкозо-6-фосфатдегидрогеназ и, напротив, активация лактатдегидрогеназы и кислой фосфатазы, маркерного фермента лизосом. Все эти изменения отражают соотношение процессов повреждения и адаптации в поврежденных нейронах в условиях отсутствия желчи в организме.

Выводы. Полная потеря желчи в течение одних, трёх и пяти суток вызывает постепенное увеличение структурных и метаболических нарушений в клетках Пуркинье коры мозжечка и гибель некоторых из них.

Ключевые слова: мозжечок, клетки Пуркинье, структура, гистохимия, потеря желчи. 